\title{
Is sexual reproduction of high-mountain plants endangered by heat?
}

\author{
Ursula Ladinig • Manuel Pramsohler • Ines Bauer • \\ Sonja Zimmermann · Gilbert Neuner · \\ Johanna Wagner
}

Received: 10 August 2014 / Accepted: 20 January 2015 / Published online: 20 February 2015

(c) The Author(s) 2015. This article is published with open access at Springerlink.com

\begin{abstract}
Strong solar irradiation in combination with still air and dry soil can cause prostrate high-mountain plants to heat up considerably and ultimately suffer heat damage. Such heat damage has been repeatedly shown for vegetative structures, but not for reproductive structures, which we expected to be particularly vulnerable to heat. Heat effects on cold-adapted plants may increase with rising global temperatures and the predicted increase in heat waves. We have tested the heat tolerance of reproductive versus vegetative shoots at different reproductive stages, comparing ten common plant species from different elevation belts in the European Alps. Plant samples were exposed to temperatures in 2-K steps of 30 min each between 42 and $56^{\circ} \mathrm{C}$. Heat damage was assessed by visual rating and vital staining. Reproductive shoots were on average $2.5 \mathrm{~K}$ less heat tolerant $\left(\mathrm{LT}_{50}\right.$, i.e. the mean temperature causing $50 \%$ heat damage, $47.2{ }^{\circ} \mathrm{C}$ ) than vegetative shoots (mean $\mathrm{LT}_{50} 49.7^{\circ} \mathrm{C}$ ). Initial heat injuries (mean $\mathrm{LT}_{10}$ ) were observed at $43-45{ }^{\circ} \mathrm{C}$ in heat-susceptible species and at $45-47^{\circ} \mathrm{C}$ in more heat-tolerant species, in at least one reproductive stage. Generally, heat tolerance was significantly higher during fruiting than during the bud stages and anthesis. Prostrate species with
\end{abstract}

Communicated by Allan T. G. Green.

Electronic supplementary material The online version of this article (doi:10.1007/s00442-015-3247-0) contains supplementary material, which is available to authorized users.

This paper is dedicated to Walter Larcher on the occasion of his 85th birthday.

U. Ladinig · M. Pramsohler · I. Bauer · S. Zimmermann ·

G. Neuner $\cdot$ J. Wagner $(\triangle)$

Institute of Botany, Faculty of Biology, University of Innsbruck,

Sternwartestraße 15, 6020 Innsbruck, Austria

e-mail: johanna.wagner@uibk.ac.at acaulescent buds and flowers tolerated heat better than those with caulescent buds and flowers. Petals were the most heatsusceptible plant structure and mature pollen the most heat tolerant. Based on these data, heat tolerance of reproductive structures appears to be adapted to the prevailing maximum temperatures which the plants experience during different reproductive stages in their environment. During hot spells, however, heat tolerance thresholds may be exceeded. More frequent heat waves would decrease the reproductive output and, consequently, the competitiveness of heat-susceptible species.

Keywords Alpine plants $\cdot$ Heat tolerance $\cdot$ Reproductive ecology $\cdot$ Risk assessment $\cdot$ Temperature stress

\section{Introduction}

High mountains are generally associated with a cold environment. However, due to strong solar irradiation, the surface temperatures of the short vegetation can considerably exceed free air temperatures (Cernusca 1976; Wilson et al. 1987). Conditions of still air and dry soil increase this effect (Körner and De Moraes 1979; Neuner et al. 1999; Buchner and Neuner 2003; Körner 2003). The extent of radiative warming essentially depends on the plant's habit. Species with prostrate shoots, including rosette plants and cushion plants, may heat up to $30-40 \mathrm{~K}$ above air temperature, and erect plants up to $20 \mathrm{~K}$ (Salisbury and Spomer 1964; Körner and Cochrane 1983; Gauslaa 1984; Körner 2003; Larcher and Wagner 2009, 2010; Neuner and Buchner 2012). Different plant statures within a stand and a variable micro-topography lead to considerable differences in plant temperatures at a small scale (Scherrer and Körner 2010; Neuner and Buchner 2012). 
Maximum leaf temperatures measured in full solar radiation during midsummer can reach, depending on the growth habit, between 30 and $50{ }^{\circ} \mathrm{C}$ (Gauslaa 1984; Körner and Larcher 1988; Buchner and Neuner 2003; Neuner and Buchner 2012), but have been recorded to reach up to $60{ }^{\circ} \mathrm{C}$ in individual cases (Larcher and Wagner 1976; Buchner and Neuner 2003). Plant temperatures that surpass $42{ }^{\circ} \mathrm{C}$ become critical and may exceed the heat tolerance threshold of that plant. Plants may respond to exposure to high temperatures with a short-term heat hardening to the rising temperature (Gauslaa 1984; Neuner et al. 2000; Buchner and Neuner 2003; Larcher et al. 2010; Neuner and Buchner 2012), but this response is not always sufficient for heat survival under extended summer conditions with strong irradiation and low precipitation (Neuner et al. 1999; Buchner and Neuner 2003; Ladinig and Wagner 2005). In heat-susceptible species, heat damage in leaves first occurs at around $43{ }^{\circ} \mathrm{C}$ (30-min shortterm heating; Larcher and Wagner 1976), with heat damage increasing rapidly once the heat tolerance threshold is passed. In the majority of alpine species, $50 \%$ heat damage $\left(\mathrm{LT}_{50}\right)$ in vegetative aboveground organs occurs between 45 and $52{ }^{\circ} \mathrm{C}$, and between 50 and $60{ }^{\circ} \mathrm{C}$ in the most heat tolerant species (data compiled for 79 species of the European Alps by Neuner and Buchner 2012). This high variability in heat tolerance can be found concomitantly among species with different growth habits in close proximity, as demonstrated by Buchner and Neuner (2001). The strong influence of habit is also expressed by the fact that mean heat tolerance in plants of the different mountain systems on earth is rather similar (Gauslaa 1984; reviewed in Körner 2003).

In contrast to vegetative organs, hardly any information is available on the heat tolerance of reproductive structures in high-mountain plants. Lowland plants are known to be most vulnerable to extreme temperatures during reproduction (Hedhly et al. 2003, 2008; Barnabás et al. 2008; Zinn et al. 2010; Hedhly 2011). Thus, it can be expected that actively growing reproductive structures of high-mountain plants are at greater risk of heat damage than vegetative ones. Evidence exists for Sempervivum montanum, whose inflorescences are fully damaged at $52{ }^{\circ} \mathrm{C}$; the same temperature is sustained by vegetative rosettes without injury (Larcher et al. 2010). In a number of high Andean plants, heat tolerance of reproductive tissues ranged from 47-51.6 ${ }^{\circ} \mathrm{C}\left(\mathrm{LT}_{50}\right)$ which was $0.7-2.3 \mathrm{~K}$ lower than in leaves (Neuner and Buchner 2012).

In the study reported here, we compared the heat tolerance of whole reproductive shoots and individual reproductive structures to vegetative shoots in ten common plant species from different vegetation zones of the European Central Alps. The species selected for study differ in their growth form (dwarf shrubs, cushion plants, herbs) and habit (erect or prostrate with acaulescent and caulescent reproductive shoots). We addressed the following questions: (1) Are there differences in heat tolerance between vegetative and reproductive structures within a species? (2) Are there differences in heat susceptibility among the main reproductive stages (bud stage, flowering, fruiting)? (3) Is there a relationship between growth form, habit and elevational distribution and heat tolerance? (4) On the basis of in situ temperature maxima, what is the potential risk of suffering heat damage during reproductive development in the respective environment?

Based on our current state of knowledge on heat effects on plants, we expected that reproductive structures would be more susceptible to heat damage than vegetative ones. As heat tolerance is an adaptive trait within the predictable environmental temperature regime (Davis and Shaw 2001; Hedhly et al. 2008), we assumed that prostrate shoots with acaulescent reproductive shoots would tolerate heat better than erect growing ones and that species adapted to higher elevations would tolerate heat less well than species from the lower elevations.

This study has also to be seen in the context of rising global temperatures and the associated increase in the number of extreme weather events. The present study should reveal which of the study species might be particularly threatened when heat waves become more frequent and severe.

\section{Materials and methods}

\section{Study species}

The ten species investigated in this study and their characteristics are summarized in Table 1. Selection criteria for plant species were:

1. Species exhibit typical growth forms for the highmountain environment (dwarf shrub, cushion plant, herb).

2. Species differ in their growth habit (vegetative shoots prostrate or erect, with acaulescent or caulescent reproductive shoots). The following habit types were distinguished: EAC, vegetative shoot erect, reproductive shoot acaulescent in bud stage $b 1$, caulescent from bud stage $b 2$ onward; PAC, vegetative shoot prostrate, reproductive shoot acaulescent in bud stage $b 1$, caulescent from bud stage $b 2$ onward; PAA, vegetative shoot prostrate, reproductive shoot acaulescent in all reproductive stages.

3. Species occur in different mountain vegetation zones: subalpine (i.e. the treeline ecotone), alpine, subnival 


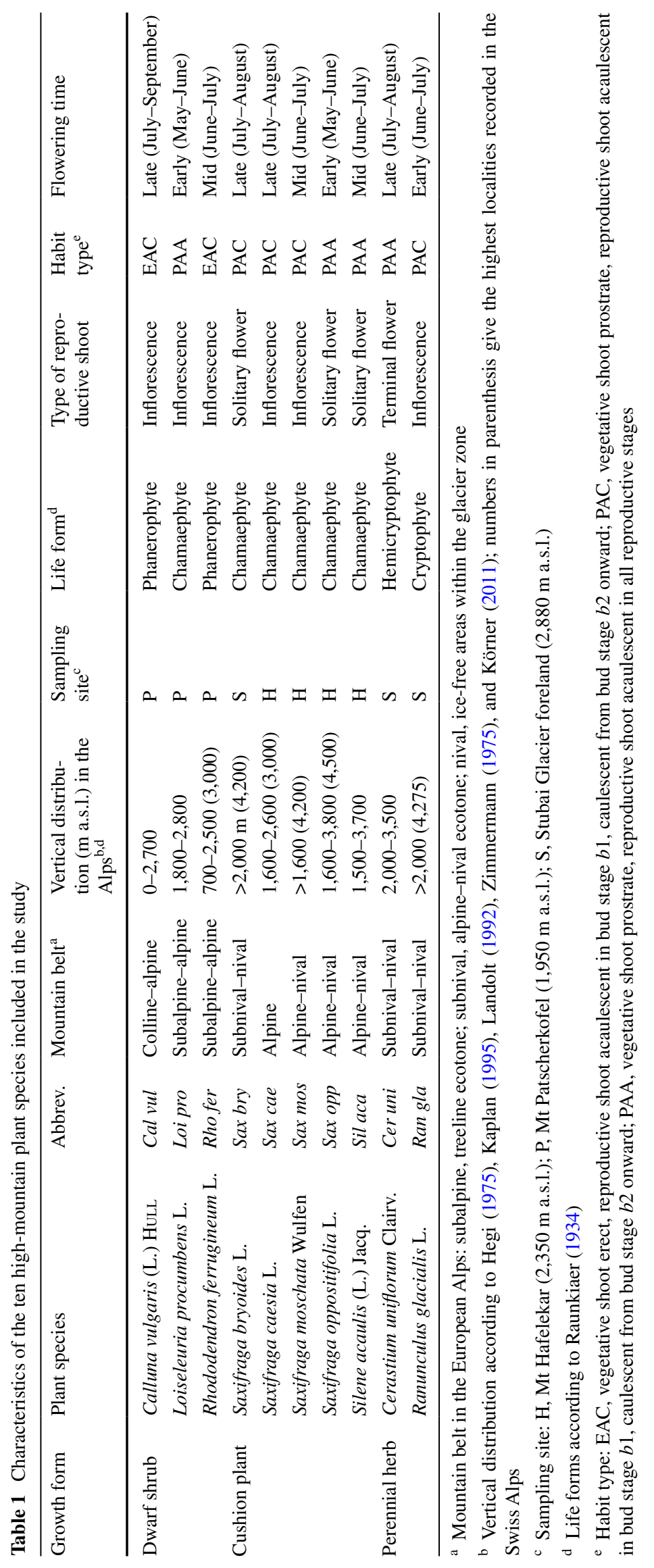


(i.e. the alpine-nival ecotone) or nival (according to Ellenberg and Leuschner 2010).

All ten species occur commonly in and are typical of their respective vegetation zone.

\section{Sampling sites}

Calluna vulgaris, Loiseleuria procumbens and Rhododendron ferrugineum were sampled in the subalpine dwarfshrub belt (west-facing slope, 1,950-2,000 m a.s.l., Mt Patscherkofel $47^{\circ} 12^{\prime} \mathrm{N}, 11^{\circ} 27^{\prime} \mathrm{E}$, Tyrolean Central Alps); Saxifraga caesia, S. moschata, S. oppositifolia and Silene acaulis were sampled in the alpine zone (west-facing sites, 2,300-2,350 m a.s.l., Mt Hafelekar, $47^{\circ} 18^{\prime} \mathrm{N}, 11^{\circ} 23^{\prime} \mathrm{E}$, Northern Calcareous Alps); Cerastium uniflorum, Ranunculus glacialis and Saxifraga bryoides were sampled in the subnival zone (north-west-facing slopes of the glacier foreland of the Stubai Glacier, 2,800-2,880 m a.s.1., 46 $59^{\prime} \mathrm{N}$, $11^{\circ} 07^{\prime} \mathrm{E}$, Tyrolean Central Alps). Plants were either excavated with root bales (cushion plants and herbs) or shoots were cut off (woody shrubs). Plant individuals were wrapped in moist filter paper and transported at temperatures between 10 and $15{ }^{\circ} \mathrm{C}$ in cooler bags to the laboratory within $1 \mathrm{~h}$ (treeline and alpine sites) and $2 \mathrm{~h}$ (subnival sites). All plants were collected in the morning when the diurnal heat tolerance was low (Buchner and Neuner 2003). Heat treatments took place immediately upon the arrival of the collected plants to the laboratory.

\section{Reproductive stages}

During the 2009 and 2012 growing seasons, heat tolerance of aboveground vegetative and reproductive shoots was determined in the following reproductive stages: bud stages $b 1$ (reproductive buds tightly closed; before peduncle/ pedicel elongation in species of habit type EAC and PAC) and $b 2$ (flower buds still closed but shortly before anthesis; during peduncle/pedicle elongation in EAC and PAC types); anthesis $a$; fruit stage $f$ (early fruit development, seeds undergo histogenesis). In $C$. vulgaris, $L$. procumbens, $C$. uniflorum and $R$. glacialis, only the bud stage $b 2$ was investigated. Depending on the state of reproductive development, the term "reproductive shoot" stands for a single flower bud, flower and fruit including the pedicel $(C$. vulgaris, L. procumbens, $R$. ferrugineum, S. bryoides, S. oppositifolia, S. acaulis, C. uniflorum) or the inflorescence bud, the inflorescence and the infructescence including the peduncle ( $S$. caesia, S. moschata, R. glacialis). The term "vegetative shoot" refers to mature stems and leaves in $C$. vulgaris, L. procumbens and $R$. ferrugineum; leafy shortstem shoots in the saxifrages and $S$. acaulis; newly forming stems and leaves of the hemicryptophyte $C$. uniflorum; leaves of the cryptophyte $R$. glacialis.
Heat treatments

Plant samples were exposed to temperatures in $2 \mathrm{~K}$ stepsranging from the temperature causing 0 to $100 \%$ heat damage - in hot water baths (Thermomix Braun; Melsungen, Germany). At each exposure temperature, 10-55 randomly selected reproductive shoots from at least ten individual plants were tested together with several leaves or, in the case of cushion plants, up to six short-stem vegetative shoots. The plant samples were loosely arranged on wet filter paper in heat-durable and watertight plastic bags. The bags were then plunged into the preheated water baths to bring them immediately to the exposure temperature. The exposure time was $30 \mathrm{~min}$, as is standard in heat tolerance tests (Kreeb 1990).

\section{Assessment of heat damage}

Heat-treated and reference samples (untreated control samples and fully heat-damaged samples that had been immersed in a $80{ }^{\circ} \mathrm{C}$ water bath) were embedded in moist cotton in small plastic boxes and kept in growth chambers (photoperiod $16 / 8 \mathrm{~h}$, temperature range $15 / 5^{\circ} \mathrm{C}$; PGC-GL, Percival Scientific Inc., Perry, IA) for 3-4 days, which was the time required for tissue necrosis to develop in the case of injury. For vegetative shoots, the percentage of visually damaged areas was assessed. Reproductive shoots were first either rated as undamaged (all visible structures intact) or damaged (at least one structure damaged). The extent of visual damage was expressed as the percentage of damaged reproductive shoots per individual. In a second step, heat damage to single reproductive structures (pedicel, petals, stamens with immature pollen, style including stigma, ovary including ovules and placenta) was detected using the vital stain TTC (2,3,5-triphenyltetrazoliumchloride; Merck KGaA, Darmstadt, Germany). Living tissues and cells turn red due to the activity of dehydrogenases, which transform the colorless TTC into the red-colored triphenyl formazan. For each exposure temperature, we incubated ten flowers from ten randomly selected reproductive shoots from each of the heat-treated and control plants in a $0.5 \%$ TTC solution in 5-ml glass vials following the measurement protocol of Neuner et al. (2013). To ensure a quick penetration of the TTC solution into the samples, ovaries were scarified with a razor blade and infiltrated with the TTC solution under vacuum. After $24 \mathrm{~h}$ of incubation in the dark at room temperature, the samples were stored in an $86 \%$ glycerol solution (Rotipuran, Roth, Germany) until further analysis. The percentage of heat damage was assessed by comparing heat-treated with reference samples under a stereo microscope (Olympus SZH; Olympus Inc., Tokyo, Japan).

Viability data from each heat treatment temperature were randomly assigned to datasets $(n=10)$ and plotted 
against the treatment temperatures. For each dataset, we fit a classic logistic function using the software OriginPro 7G SR4 (OriginLab Corp., Northampton, MA). The following threshold values for heat damage were read from the curve-fitting protocol for each replicate: $\mathrm{LT}_{10}, \mathrm{LT}_{50}, \mathrm{LT}_{90}$ (temperatures causing 10, 50 and $90 \%$ heat damage) and $\mathrm{LT}_{100}$ (lowest temperature causing $100 \%$ heat damage). We calculated the mean $\mathrm{LT}_{10}, \mathrm{LT}_{50}, \mathrm{LT}_{90}$ and $\mathrm{LT}_{100}$ from the single values of each dataset.

Investigation of heat tolerance of mature pollen grains

The heat tolerance of mature pollen was not unambiguously detectable by TTC and therefore was investigated separately via in vitro pollen germination and pollen-tube growth assays. Freshly opened anthers were collected in Eppendorf tubes and heated in a blockheater (Stuart Block Heaters, Camlab Inc., Cambridge, UK) for 30 min. Heat treatments were conducted at 5-K steps at temperatures from $40{ }^{\circ} \mathrm{C}$ until $100 \%$ of the pollen grains had been heatkilled (no germination ascertainable). Pollen from ten different individuals, ten flowers each (C. uniflorum, $R$. ferrugineum, $S$. caesia, $S$. moschata, $S$. bryoides) and three to five flowers each $(R$. glacialis) were separately tested at each temperature step.

Heat-treated pollen of each individual was spread onto glass slides on solidified germination medium according to Boavida and McCormick (2007). Depending on the species, the optimum sucrose concentration was between 10 and $30 \%$. The glass slides were placed in moisture incubation chambers at $25{ }^{\circ} \mathrm{C}$. Pollen germination counts were made at random in six fields per glass slide under a microscope at $20 \times$ magnification (Olympus, BX50) the day after. A pollen grain was classified as germinated if the length of the pollen tube was equal to or greater than the diameter of the pollen grain.

\section{Site temperatures}

Air temperatures $2 \mathrm{~m}$ aboveground (referred to subsequently as $2 \mathrm{~m}$ air temperatures) from standard weather stations were provided by the Central Institute for Meteorology and Geodynamics, Austria (ZAMG) for Mt Patscherkofel (alpine zone, 2,246 m a.s.l., $47^{\circ} 12^{\prime} 31^{\prime \prime} \mathrm{N}$, $11^{\circ} 27^{\prime} 38^{\prime \prime} \mathrm{O}$ ) and Pitztal Gletscher (subnival zone, 2,840 m a.s.l., $46^{\circ} 55^{\prime} 36^{\prime \prime} \mathrm{N}, 10^{\circ} 52^{\prime} 46^{\prime \prime} \mathrm{E}$, Tyrolean Central Alps). For the subalpine site (Mt Patscherkofel, 1,950 m a.s.1.) an automated weather station (CR10; Campbell Scientific, Logan, UT; operated by G. Wieser) provided the air temperature data.

Leaf canopy temperatures were recorded at hourly intervals at subnival sites (Stubai Glacier, 2,880 m a.s.l.; Pitztal Glacier, 2,840 m a.s.1.), alpine sites (Mt Hafelekar, 2,350 m a.s.l.) and a subalpine site (Mt Patscherkofel, 1,950 m a.s.l.) using small data loggers (Tidbit, Onset, Bourne, MA). We recorded measurements throughout the year at all sites. The study period differed in terms of duration for the sites: Mt Hafelekar, Stubai Glacier (2002-2012); Pitztal Glacier (2007-2009); Mt Patscherkofel (2009-2011). Temperature loggers were placed between short-stem shoots in plant cushions or mounted in the leaf canopy of Rhododendron shrubs. During the growing season, additional loggers were mounted on supports at the height of the flowers and shaded by white plastic caps to avoid overheating.

We also recorded the leaf temperatures of dwarf shrubs, cushion plants and herbs in their respective environment using fine-wire thermocouples connected to data loggers (CR10; Campbell Scientific) that collected temperature records from the sensors every $5 \mathrm{~min}$ and calculated 30-min means. The study periods were 1998-2004 and 2008 at subalpine sites, 1998-2000 and 2009 at alpine sites and 2009 at a subnival site. Bud and flower temperatures were repeatedly recorded during shorter periods.

Plant temperatures measured in individual leaves and flowers in the vicinity of the standard weather stations (distance from station 50-500 m) were screened for absolute temperature maxima. Using the recorded data on $2 \mathrm{~m}$ air temperature, we determined the mean number of summer days (June-August) with temperature maxima of $\geq 12{ }^{\circ} \mathrm{C}$ in the different temperature classes (range $2 \mathrm{~K}$ ) for 2002 2012. To visualize heat accumulation in prostrate plants (habit types PAC in the $b 1$ stage and PAA), daily maximum 30-min plant temperatures were related to the respective daily maximum $2 \mathrm{~m}$ air temperatures recorded on the same day at the same site.

\section{Infrared video thermography}

Infrared thermography was carried out on S. moschata and $S$. acaulis at the alpine site on the west- and south-exposed slopes on Mt Hafelekar (2350 m a.s.l.) on 19 June 2012, a warm clear day, between 2 and 4 p.m. Maximum $2 \mathrm{~m}$ air temperature was $14.6{ }^{\circ} \mathrm{C}$. The infrared camera (ThermaCAM S60; FLIR Systems AB, Danderyd, Sweden) was equipped with a close-up lens (LW 64/150) for macro images of single flowers. For field measurements, the camera was mounted on a tripod and connected to a notebook to control measurements and record the data. The infrared images were recorded at a measurement interval of $400 \mathrm{~ms}$. Further analysis of the infrared images was carried out with the software ThermaCAM Researcher Pro 2.8 (Flir Systems $\mathrm{AB})$.

Plant temperatures were also registered with a set of eight copper constantan thermocouples (Type $\mathrm{T}$, solder junction diameter $0.3 \mathrm{~mm}$ ) connected to a data logger (DaqPRO 5300; Fourier Systems, www.fouriersystems.com) at a measurement 
interval of $1 \mathrm{~s}$ to provide reference temperatures. The thermocouples were fixed to the different plant parts with a medical tape permeable to gases ( $3 \mathrm{M}^{\mathrm{TM}}$ Transpore).

\section{Statistics}

Heat tolerance data were normally distributed (checked by Q-Q Plots), allowing parametric tests. Significant differences in heat tolerance among species, species groups and reproductive stages, and between vegetative and reproductive shoots, were tested for using either the Student's $t$ test or one-way analysis of variance (ANOVA). In the case of homoscedasticity (checked by Levene's test) the Bonferroni post hoc test was used, otherwise we used the Tukey post hoc test. The effects and interactions of the factors "species," "reproductive stage" (bud stage $b 1, b 2$, anthesis, fruiting) and "reproductive structure" (pedicel, petals, style, ovary) on heat tolerance $\left(\mathrm{LT}_{50}\right)$ were analyzed using a fixed effect GLM ANOVA. In all tests, the critical level of significance was $\alpha=0.05$. All statistical analyses were carried out using the statistical software SPSS (SPSS, Chicago, IL).

\section{Results}

Heat tolerance of vegetative shoots

Heat tolerance of the vegetative shoots varied significantly among species depending on the developmental stage (species $\times$ stage interaction, $\left.F_{20,339}=5.74 ; P<0.001\right)$. Mean heat tolerance of vegetative shoots $\left(\mathrm{LT}_{50}\right)$ over all reproductive stages was highest in $S$. oppositifolia $\left(>52{ }^{\circ} \mathrm{C}\right)$, followed by the dwarf shrubs $C$. vulgaris and $L$. procumbens and the cushion plant $S$. acaulis (around $51^{\circ} \mathrm{C}$ ). Heat tolerance was lowest in $R$. glacialis (around $46^{\circ} \mathrm{C}$ ). $\mathrm{LT}_{50}$ values for the remainder of species ranged between $48^{\circ}$ and $50{ }^{\circ} \mathrm{C}$ [Fig. 1; Electronic Supplementary Material (ESM) Table $\mathrm{S} 1$ for mean $\mathrm{LT}_{50}$ values and statistics).

First heat damage $\left(\mathrm{LT}_{10}\right)$ and $90 \%$ damage $\left(\mathrm{LT}_{90}\right)$ occurred at temperatures on average 1-2 $\mathrm{K}$ lower and higher, respectively, than $\mathrm{LT}_{50}$ (Fig. 1; ESM Table S2 for mean $\mathrm{LT}_{10}$ values and statistics). In half of the species, vegetative shoots were totally damaged $\left(\mathrm{LT}_{100}\right)$ at about $52{ }^{\circ} \mathrm{C}$, in $R$. glacialis already at $50^{\circ} \mathrm{C}$, and in C. vulgaris, L. procumbens, S. oppositifolia and $S$. acaulis at $54-56{ }^{\circ} \mathrm{C}$.

Heat tolerance $\left(\mathrm{LT}_{50}\right)$ of vegetative shoots tended to increase during reproductive development (Fig. 2a); however, this was only significant in C. vulgaris, L. procumbens and R. ferrugineum (for details see ESM Table S1). With respect to the growth form, woody species turned out to be most heat tolerant (mean \pm standard deviation (SD): $\left.50.4 \pm 1.3^{\circ} \mathrm{C}\right)$, followed by cushion plants $\left(49.4 \pm 1.4{ }^{\circ} \mathrm{C}\right)$ and herbs $\left(47.3 \pm 1.8^{\circ} \mathrm{C}\right.$ ) (Fig. $2 \mathrm{~b} ; P<0.001$, one-way

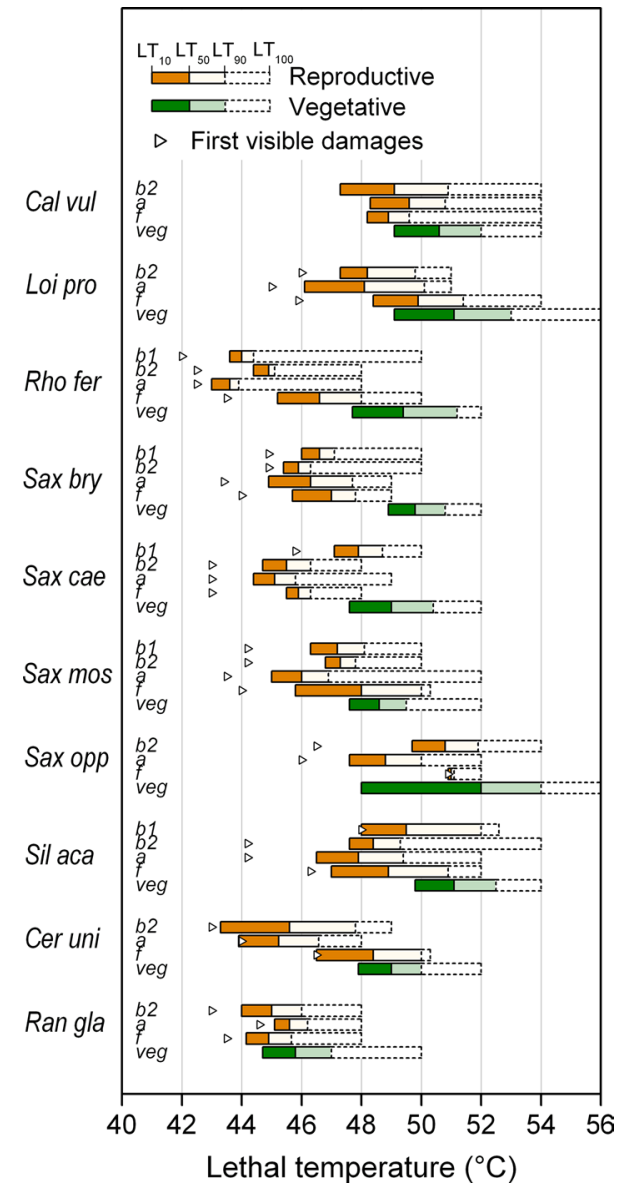

Fig. 1 Heat tolerance of reproductive shoots in different reproductive stages ( $b 1$ reproductive buds tightly closed; $b 2$ reproductive buds shortly before anthesis, during peduncle/pedicel elongation of caulescent shoots; $a$ anthesis; $f$ early fruit development) and of vegetative shoots (veg). Horizontal bars range from mean $\mathrm{LT}_{10}$ [lethal temperatures (LT) causing $10 \%$ damage] to $\mathrm{LT}_{100}$ (LT causing $100 \%$ damage) (from left to right). The range between mean $\mathrm{LT}_{10}$ and $\mathrm{LT}_{50}$ is given in dark orange (reproductive shoots) and dark green (vegetative shoots), the range between mean $\mathrm{LT}_{50}$ and $\mathrm{LT}_{90}$ is shown in light orange and light green, respectively. Triangles mark temperatures where the first damage became visible in single reproductive shoots. For the abbreviation of species names, see Table 1. For the definitions of $\mathrm{LT}_{10}$ to $\mathrm{LT}_{100}$, see section "Assessment of heat damage". In all investigated species, vegetative shoots were significantly more heat tolerant than reproductive shoots (intraspecies comparisons between $\mathrm{LT}_{50}$ values vegetative vs. reproductive across all developmental stages $P<0.001, t$ test). For statistical differences among reproductive stages, see Electronic SM Tables S1 and S2

ANOVA). Species from higher elevations tolerated less heat than species from lower elevations (Fig. 2c; $P<0.001$, one-way ANOVA).

Heat tolerance of reproductive shoots

Reproductive shoots tolerated significantly less heat than vegetative shoots (Fig. 1), at least in single reproductive 


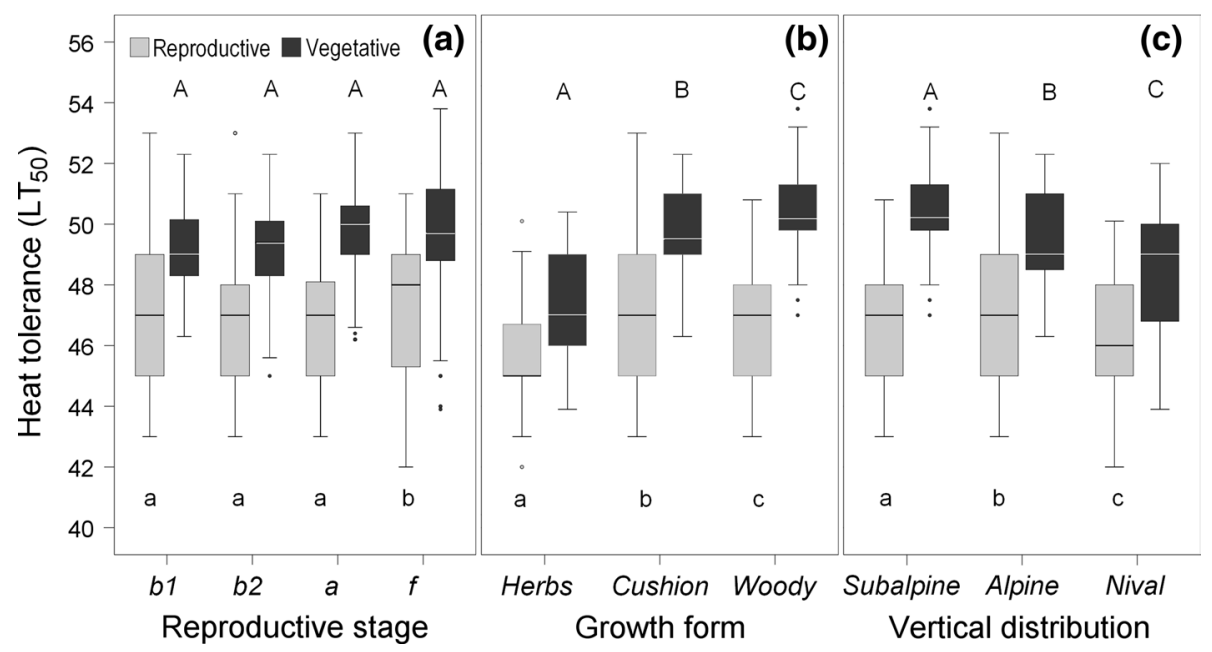

Fig. 2 Heat tolerance $\left(\mathrm{LT}_{50}{ }^{\circ} \mathrm{C}\right)$ of vegetative shoots (black bars) and of reproductive shoots (gray bars). Data for the species were pooled and grouped by different reproductive stages (a), different growth forms (b) and different mountain vegetation zones (c). Box plots show the median (horizontal line inside box), the 25 th and 75 th percentile (top and bottom of box), maximum and minimum values

stages (for details see ESM Tables S1 and S2). Over all species and reproductive stages, the mean difference for $\mathrm{LT}_{50}$ amounted to $2.5 \mathrm{~K} \pm 1.2 \mathrm{SD}$. The mean difference over all reproductive stages was small and not significant in $R$. glacialis $(0.7 \mathrm{~K} \pm 0.5)$, but it was clear-cut and significant in the remainder of species, particularly in $S$. bryoides (3.4 $\mathrm{K} \pm 0.5$ ) and $R$. ferrugineum $(3.7 \mathrm{~K} \pm 0.8)$. The difference in $\mathrm{LT}_{50}$ was larger in woody $(2.6 \mathrm{~K} \pm 1.2)$ and cushion plants $(2.6 \mathrm{~K} \pm 1.1)$ than in herbs $(1.8 \mathrm{~K} \pm 1.5)$.

Heat tolerance of reproductive shoots varied among species depending on the stage (species $\times$ stage interaction, $\left.F_{21,1082}=5.13 ; P<0.001\right)$. Reproductive shoots were particularly heat susceptible in $R$. glacialis throughout the whole reproductive developmental period $\left(\mathrm{LT}_{50}\right.$ of approx. $45^{\circ} \mathrm{C}$ ), in $S$. caesia after peduncle elongation $\left(\mathrm{LT}_{50} 45-46{ }^{\circ} \mathrm{C}\right)$ and in $R$. ferrugineum from $b 1$ until anthesis ( $\mathrm{LT}_{50}$ of approx. $44{ }^{\circ} \mathrm{C}$ ) (Fig. 1; ESM Table S1). Reproductive shoots of $S$. oppositifolia were the most heat tolerant $\left(\mathrm{LT}_{50} 49-51{ }^{\circ} \mathrm{C}\right)$, followed by $C$. vulgaris $\left(\mathrm{LT}_{50}\right.$ of approx. $49{ }^{\circ} \mathrm{C}$ ), L. procumbens and $S$. acaulis $\left(\mathrm{LT}_{50}\right.$ of approx. $48-50{ }^{\circ} \mathrm{C}$ ). First damage to single flowers occurred at considerably lower temperatures-at around 42-43 ${ }^{\circ} \mathrm{C}$ in $R$. ferrugineum, C. uniflorum and R. glacialis; at around $44^{\circ} \mathrm{C}$ in $S$. bryoides, S. caesia, S. moschata and $S$. acaulis, at $>45{ }^{\circ} \mathrm{C}$ in $C$. vulgaris, L. procumbens and $S$. oppositifolia. This ranking of species according to heat susceptibility clearly shows that nival plants are among the most vulnerable of the plant species tested. The order of the remainder of species, however, does not reflect their environment (alpine, subalpine) but rather their habit within the normal range (whiskers) and outliers (circles). Different letters within subfigures indicate statistical differences among different groups for vegetative shoots (uppercase letters) and for reproductive shoots (lowercase letters) by one-way ANOVA. Mean values of $\mathrm{LT}_{50}$ are significantly different between reproductive and vegetative shoots in all groups $(P \leq 0.001, t$ test $)$

(buds and flowers caulescent or acaulescent; for details see next paragraph).

Taking all species together, heat tolerance $\left(\mathrm{TL}_{50}\right)$ was significantly higher during early fruiting than during the bud stages and anthesis (Fig. 2a; $P<0.004$, one-way ANOVA). Pooling all reproductive stages together, reproductive shoots of herbs tolerated significantly less heat than those of cushion plants and woody plants (Fig. 2b; $P<0.001$, one-way ANOVA). With regard to the elevational distribution, nival species were significantly more heat susceptible than species from the alpine and subalpine zone (Fig. 2c; $P<0.001$, one-way ANOVA).

Heat tolerance of individual reproductive structures

Heat tolerance of individual reproductive structures was significantly species-dependent (species $\times$ structure interaction, $F_{26,1082}=3.33 ; P<0.001$ ). Across all species and reproductive stages, petals were significantly the most heatsusceptible plant structure, and pollen the most heat tolerant (Fig. 3a; $P<0.001$, one-way ANOVA). When classified into reproductive stages, most structures tended to be most heat susceptible during the $b 2$ stage, but the differences among stages within a structure were mostly not significant (Fig. 3b; stage $\times$ structure interaction, $F_{7,1082}=1.26$; $P=0.269$ ). Prostrate-growing vegetative shoots of the habit types PAC and PAA tolerated significantly more heat than erect vegetative shoots of the habit type EAC (Fig. 4a; $P<0.001, t$ test). Equally, acaulescent reproductive shoots (habit types PAA, PAC in bud stage $b 1$ ) were significantly 
Fig. 3 Heat tolerance $\left(\mathrm{LT}_{50}{ }^{\circ} \mathrm{C}\right)$ of whole reproductive shoots and individual reproductive structures across all reproductive stages (a) and reproductive structures itemized by reproductive stages (b): $b 1$ (light blue), b2 (dark blue), a (red), f(black). For the specification of the box plots, see caption to Fig. 2. Different letters in (a) indicate statistical differences among different reproductive structures and in (b) statistical differences among different reproductive stages within a reproductive structure (one-way ANOVA)

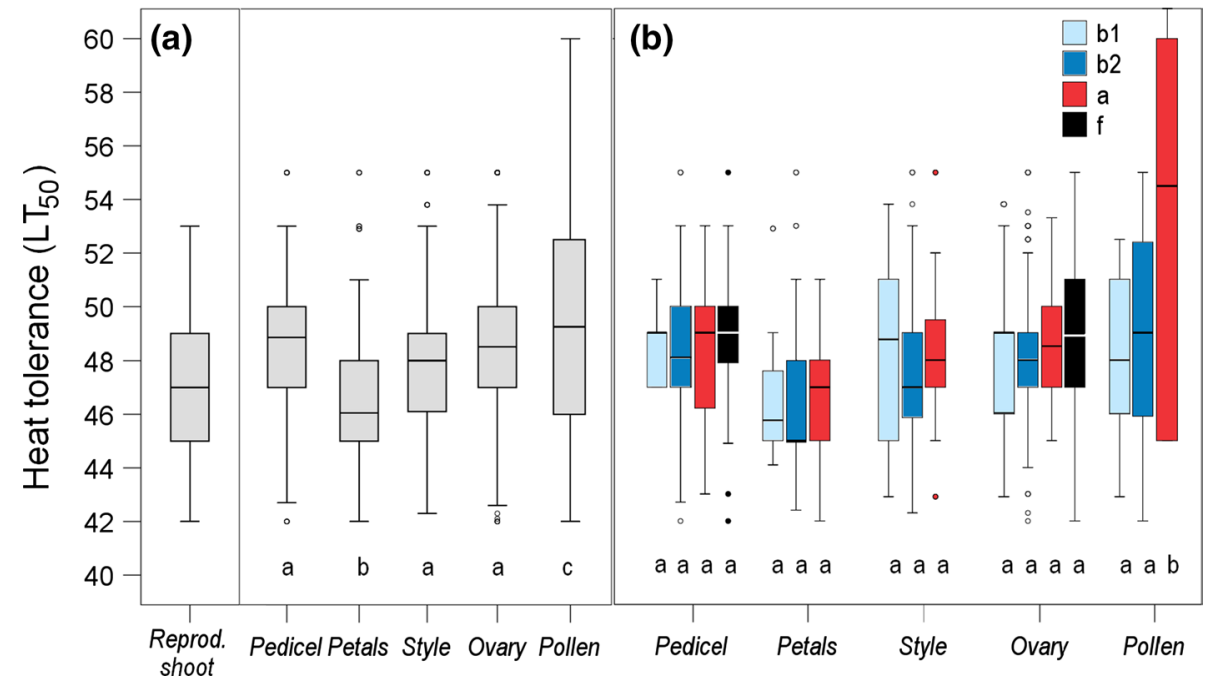

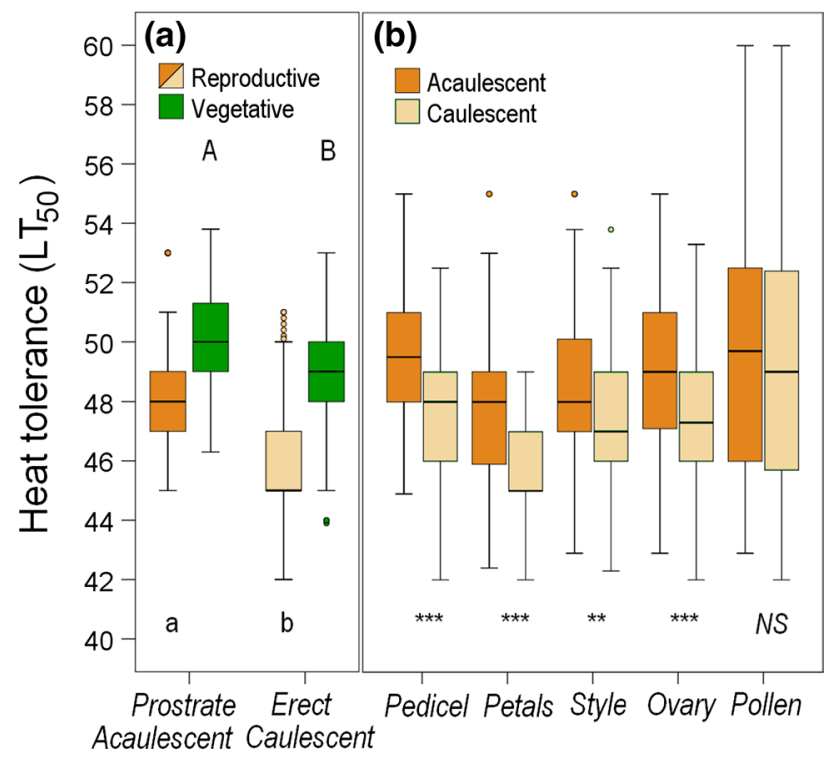

Fig. 4 Heat tolerance $\left(\mathrm{LT}_{50}{ }^{\circ} \mathrm{C}\right)$ according to shoot habit. a Prostrate vs. erect vegetative shoots (green boxes), and acaulescent vs. caulescent reproductive shoots (orange boxes), b individual reproductive structures of reproductive acaulescent (dark-orange boxes) and reproductive caulescent shoots (light-orange boxes). For the specification of the box plots see the caption to Fig. 2. Different letters in (a) indicate statistical differences between prostrate and erect vegetative shoots (uppercase letters, $P<0.001, t$ test) and between reproductive acaulescent and caulescent shoots (lowercase letters, $P<0.001, t$ test). Asterisks in (b) indicate significant differences between caulescent and acaulescent shoots within individual reproductive structures $(* * P \leq 0.01, * * * P \leq 0.001, N S$ not significant; $t$ test $)$

more heat tolerant $(P<0.001, t$ test $)$ than caulescent reproductive shoots (habit type PAC after peduncle/pedicle elongation) and reproductive shoots of the EAC type in all stages. In detail, the differences were significant for all reproductive structures except for pollen (Fig. 4b).

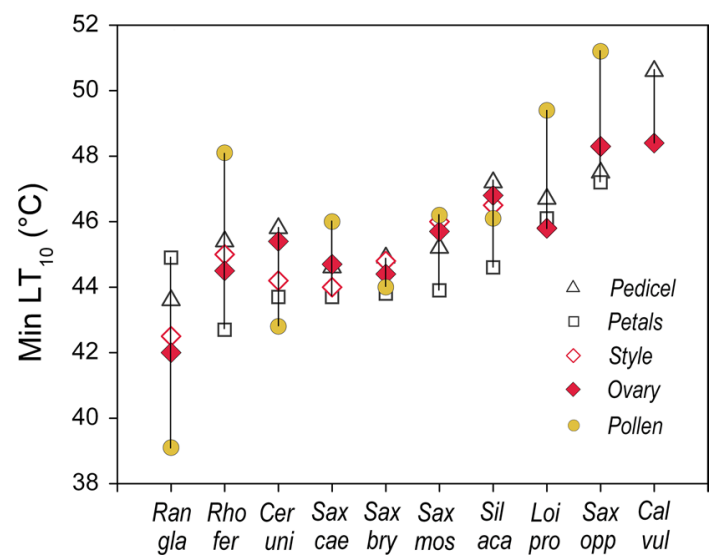

Fig. 5 Lowest mean $\mathrm{LT}_{10}\left({ }^{\circ} \mathrm{C}\right)$ for the reproductive structures pedicel (open triangle), petals (open square), style + stigma (red open diamond), ovary (red filled diamonds) and pollen (yellow filled circles) observed across all reproductive stages within a species. Vertical lines range between the most heat-susceptible and most heat-tolerant reproductive structure. For the abbreviation of species names, see Table 1

Within a species at the same reproductive stage, the different reproductive structures showed-except for pollen-about the same threshold values for $\mathrm{LT}_{50}$ (for details see ESM Table S1). Significant differences in heat tolerance between the pedicel, style and ovary were found only in single species during single reproductive stages. The lowest mean $\mathrm{LT}_{10}$ value for each reproductive structure of each species observed across all reproductive stages was recorded for petals, whereas-apart from pollen-peduncles were the most heat tolerant structures (Fig. 5; see ESM Table S2 for species-specific details). The ranking of species according to the most heat-susceptible reproductive structure was found to be about the same as that for whole reproductive shoots (compare Fig. 1) and reflects the heat 


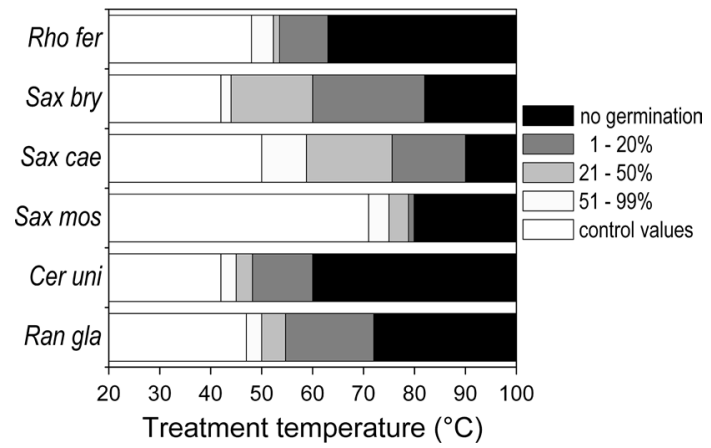

Fig. 6 Heat tolerance of mature pollen grains. Bars pollen germination [as percentage of germination of respective control value (percentage germination of untreated pollen)] after heat treatment at different temperatures. White bars $100 \%$ relative germination (compared to control value), very light gray 51-99\%, light gray 21-50\%, dark gray 1-20\%, black no germination. For the abbreviation of species names, see Table 1

load that the respective plants may be subjected to at their natural growing sites. The nival species $R$. glacialis and $C$. uniflorum and the erect shrub $R$. ferrugineum were the most heat susceptible, cushion plants with caulescent flowers/ inflorescences fell in the midfield range of heat susceptibility and flat-growing species of the PAA type and Calluna tolerated the most heat.

As stated already, the heat tolerance of pollen differed considerably from that of the other reproductive structures. Pollen proved to be the most vulnerable structure during the bud stage in the nival species $R$. glacialis $\left(\mathrm{LT}_{10} 39^{\circ} \mathrm{C}\right)$, and during anthesis in $C$. uniflorum and S. bryoides (Fig. 6; details in ESM Tables S1 and S2). In the remainder of the species, pollen tolerated higher temperatures than all other reproductive tissues; this tolerance was particularly pronounced in mature pollen (Fig. 6): pollen germination was largely unaffected until $50{ }^{\circ} \mathrm{C} ; S$. moschata pollen was unaffected up to $70{ }^{\circ} \mathrm{C}$.

Site temperatures and the risk of heat damage

In situ infrared thermography on the cushion plant $S$. moschata on a bright summer day clearly showed that acaulescent reproductive buds had about the same temperature as the leaf canopy (Fig. 7a, b), whereas caulescent inflorescences were significantly cooler (Fig. 7c, d). In contrast, acaulescent flowers of $S$. acaulis were equally warm or only slightly cooler than the leaf canopy (Fig. 7e, f). Within a single flower, the ovary was the warmest structure, whereas stamens and petals heated up less (Fig. 8).

Absolute $2 \mathrm{~m}$ air temperature maxima between 2002 and 2012 in the summer months June-August were $25.9^{\circ} \mathrm{C}$ at the treeline, $22.9{ }^{\circ} \mathrm{C}$ at the alpine site and $17.7^{\circ} \mathrm{C}$ at the subnival site. Maximum plant temperatures were considerably higher and depended mainly on plant habit. Leaves of $R$. ferrugineum shrubs situated about $70 \mathrm{~cm}$ aboveground heated up to a maximum of $36{ }^{\circ} \mathrm{C}$ (30-min means), which did not pose any risk for vegetative shoots (lowest mean $\mathrm{LT}_{10} 45.4{ }^{\circ} \mathrm{C}$ ) or reproductive structures at the same height
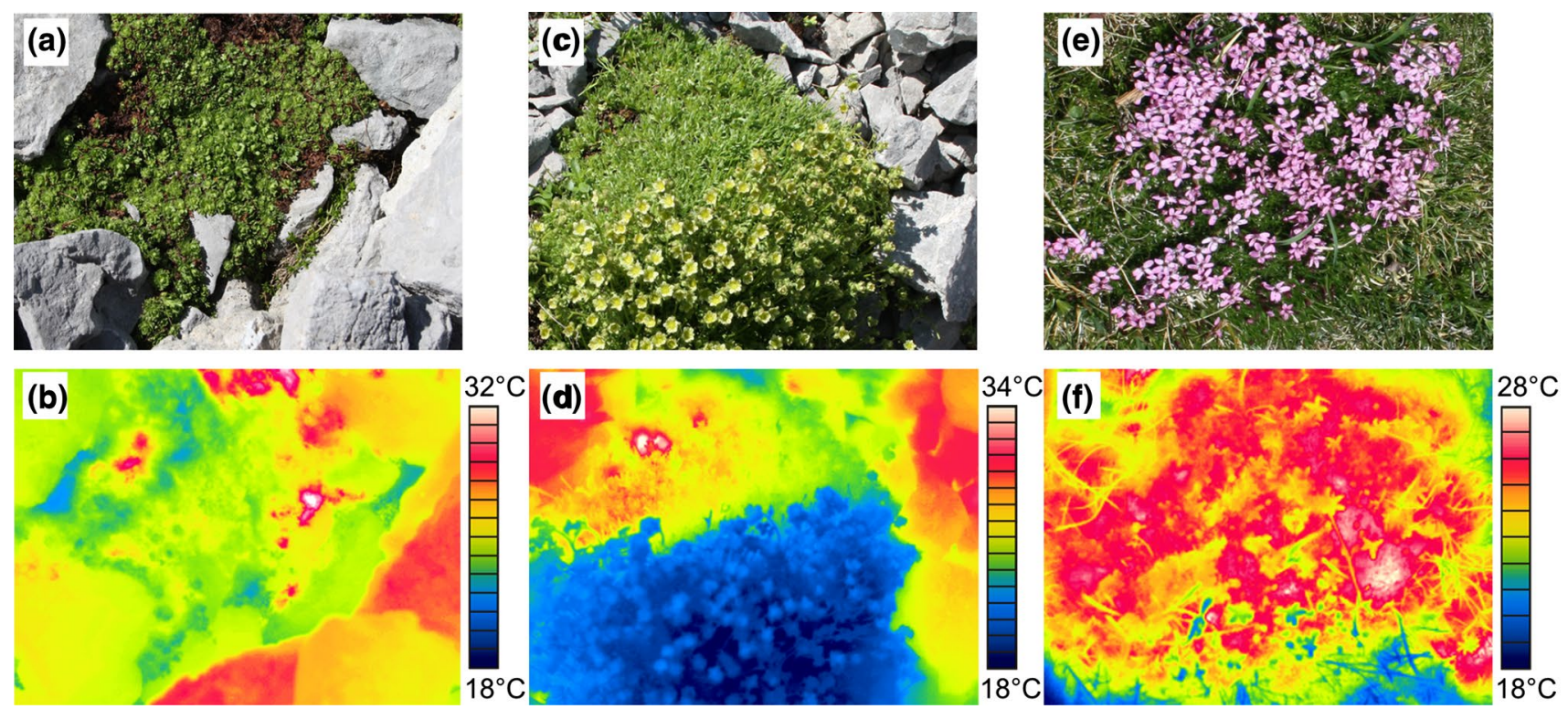

Fig. 7 Temperature distribution within cushion plants measured with infrared thermography on a clear day at an alpine site. a, b Saxifraga moschata cushion with reproductive buds before peduncle elongation (a), with about the same temperature as the leaf canopy (b), c, d $S$. moschata cushion with caulescent inflorescences during anthesis (c), which are much cooler than the prostrate leaf canopy (d); e, f Silene acaulis cushion with acaulescent flowers (e) which have about the same temperature as the leaf canopy or are only slightly cooler (f) 


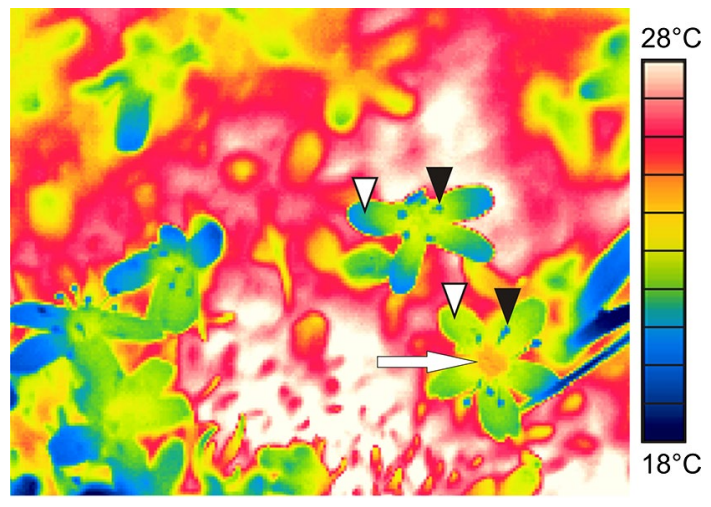

Fig. 8 Temperature distribution in flowers of Silene acaulis displayed by infrared thermography. The ovary (arrow) heats up more than stamens (filled arrowheads) and petals (open arrowheads)

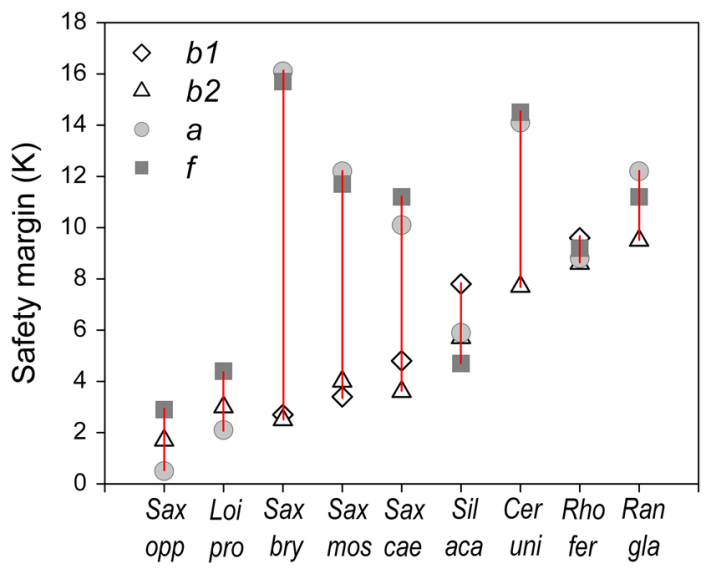

Fig. 9 Safety margin (in Kelvin) between the temperature threshold causing $\mathrm{LT}_{10}$ and maximum temperatures of reproductive shoots recorded at the growing site during early bud stage $b 1$ (diamond), late bud stage $b 2$ (triangle), anthesis a (gray circle) and early fruit development $f$ (black square) in the different species (for species names, see Table 1). Vertical lines mark the range between the lowest and highest safety margin during reproductive development

(lowest mean $\mathrm{LT}_{10} 42.7^{\circ} \mathrm{C}$ for petals) (Fig. 9). In contrast, the leaf canopy of the prostrate $L$. procumbens (PAA habit) reached $44{ }^{\circ} \mathrm{C}$, which is near the temperature threshold causing first heat damage in reproductive tissues (lowest mean $\mathrm{LT}_{10} 45.7^{\circ} \mathrm{C}$ for ovaries). Canopy temperatures measured in cushion plants usually remained $<40{ }^{\circ} \mathrm{C}$, and temperatures in flowers usually remained $<35{ }^{\circ} \mathrm{C}$. During hot and dry periods, however, canopy temperatures of cushion plants could reach up to $48{ }^{\circ} \mathrm{C}$ (S. oppositifolia, PAA habit), which is in the range of temperatures causing the first heat damage in acaulescent flower buds and flowers (compare Fig. 1). Leaves of the herbs $C$. uniflorum and $R$. glacialis reached maximum temperatures of 38 and $35{ }^{\circ} \mathrm{C}$, respectively; their flowers and inflorescences,
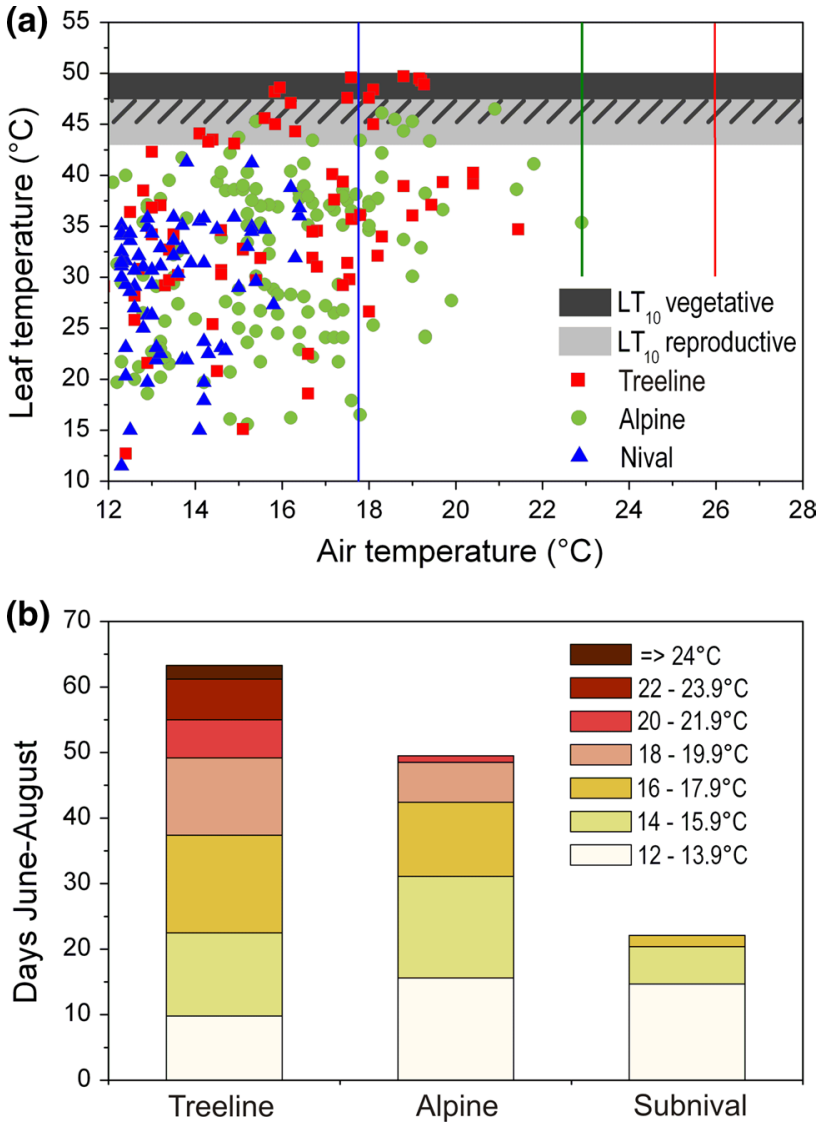

Fig. 10 Risk of heat damage for species with prostrate reproductive and vegetative shoots in the different mountain zones. a $2 \mathrm{~m}$ air temperature maxima $\geq 12{ }^{\circ} \mathrm{C}$ and 30 -min plant temperature maxima measured in single individuals on the same day at the treeline (red squares), at the alpine sites (green filled circles) and at the subnival site (blue triangles). Horizontal bars mark the range for $\mathrm{LT}_{10}$ in reproductive shoots (gray) and vegetative shoots (black). The ranges for reproductive high and vegetative low heat tolerance overlap (hatched area). Vertical lines mark maximum air temperatures occurring at the respective sites (red treeline, green alpine, blue subnival). b Mean number of summer days per season (June-August) and site with $2 \mathrm{~m}$ air temperature maxima in the specified temperature classes

$30-33{ }^{\circ} \mathrm{C}$. This results in a broad safety margin of about $8 \mathrm{~K}$ between maximum plant temperatures and $\mathrm{LT}_{10}$ for heat damage (Fig. 9) at the subnival growing sites.

At all sites, plant temperatures of $>40{ }^{\circ} \mathrm{C}$ were recorded nearly exclusively on days on which the $2 \mathrm{~m}$ air temperature maxima were $\geq 12{ }^{\circ} \mathrm{C}$. On days exceeding this air temperature threshold, the canopy of prostrate plants was on average $19.0 \mathrm{~K} \pm 10.1 \mathrm{SD}$ (maximum $33 \mathrm{~K}$ ) warmer than the air temperatures at the treeline site, at the alpine site $16.1 \mathrm{~K} \pm 7.4$ (maximum $30 \mathrm{~K}$ ), and at the subnival site $15.0 \mathrm{~K} \pm 8.0$ (maximum $27.5 \mathrm{~K}$ ). When the maximum canopy temperatures are plotted against the maximum $2 \mathrm{~m}$ air temperatures on the same days and combined with temperature thresholds for $\mathrm{LT}_{10}$ in reproductive and vegetative 
shoots (Fig. 10a), there is practically no risk of heat damage at subnival sites, but there is a potential risk at the alpine and subalpine sites. Based on this plot, for heat-susceptible species, daily maximum air temperatures of $>14{ }^{\circ} \mathrm{C}$ may already pose a risk to reproductive tissues; for more heattolerant species, the risk range would begin at $16{ }^{\circ} \mathrm{C}$. For vegetative shoots, the critical threshold air temperature is $16{ }^{\circ} \mathrm{C}$ for heat-susceptible species and $18{ }^{\circ} \mathrm{C}$ for more heattolerant species. On the basis of the $2 \mathrm{~m}$ air temperatures, the mean number of risk days per summer season on which prostrate plants could potentially suffer from heat damage is then rather high at the treeline $(53.5 \pm 5.5$ days, range 32-82 days), where $25.9 \pm 6.5$ days be classified as highrisk days (air temperatures of $>16^{\circ} \mathrm{C}$ ) (Fig. 10b). In the alpine zone, there are $33.8 \pm 5.6$ risk days and $18.4 \pm 4.7$ high-risk days.

\section{Discussion}

Comparison of heat tolerance in vegetative versus reproductive shoots

Among the ten study plants, heat tolerance of vegetative shoots was in the range of earlier findings (Buchner and Neuner 2003; compiled in Neuner and Buchner 2012): mean $\mathrm{LT}_{50}$ for herbs was around $46{ }^{\circ} \mathrm{C}$ for $R$. glacialis $\left(45-48{ }^{\circ} \mathrm{C}\right)$ and $49^{\circ} \mathrm{C}$ for $C$. uniflorum $\left(47^{\circ} \mathrm{C}\right)$; for cushion plants it was between 48 and $52{ }^{\circ} \mathrm{C}\left(46-55^{\circ} \mathrm{C}\right)$ and for dwarf shrubs between 48 and $51{ }^{\circ} \mathrm{C}\left(46-52{ }^{\circ} \mathrm{C}\right)$, where the values in parenthesis are $\mathrm{LT}_{50}$ values for the same species or growth form found in earlier studies. The variability among different investigations for the same species might result from different environmental preconditioning at different investigation sites, including daytime and short-term heat hardening during warmer periods (Gauslaa 1984; Neuner et al. 2000; Buchner and Neuner 2003; Larcher et al. 2010; Neuner and Buchner 2012), but also from different experimental methods (Buchner et al. 2013).

As expected, reproductive structures tolerated less heat ( $2.5 \mathrm{~K}$ on average) than vegetative ones; heat susceptibility tended to be highest during peduncle/pedicel elongation and/or anthesis, likely due to expanding and differentiating cells being most vulnerable to stress due to complex structural changes. Therefore, these phases generally become a weak link under temperature stress (Taschler et al. 2004; Neuner and Beikircher 2010; Zinn et al. 2010; Ladinig et al. 2013). In most species, the petals became heat damaged before other reproductive structures showed injuries. In addition to the vulnerability of petal tissues, heat stress-induced ethylene or abscisic acid synthesis might have accelerated the decay (Tripathi and Tuteja 2007; van Doorn and Woltering 2008). Except for R. glacialis and
L. procumbens, pistils (stigma, style and ovary together) tolerated up to $3 \mathrm{~K}$ (S. moschata, S. bryoides) higher temperatures than petals, at least during one reproductive stage. In particular, the compact pistils of the saxifrages sustained the most heat, possibly related to the center of a flower heating up most due to low convection and irradiation potentially being trapped inside the bowl-shaped flowers (compare Fig. 8; Kevan 1975; Stanton and Galen 1989; Luzar and Gottsberger 2001; Galen and Stanton 2003; Rejšková et al. 2010; Dietrich and Körner 2014).

Among all reproductive structures, pollen showed highest variability in heat tolerance. Pre-anthesis pollen was the weakest link in the heat-susceptible species $R$. glacialis and C. uniflorum, but was the most heat-tolerant structure in most of the remaining species. Mature pollen was mostly affected at temperatures of $\geq 50{ }^{\circ} \mathrm{C}$. Full loss of germinability, however, was caused by temperatures $\left(60-90{ }^{\circ} \mathrm{C}\right)$ which are not to be expected at the natural growing sites. Heat susceptibility of mature pollen generally depends on its water content at dispersal, which can range from a small percentage up to about $70 \%$ (Nepi et al. 2001; Franchi et al. 2002). Dry pollen is desiccation tolerant and because of high levels of late embryogenesis abundant (LEA) proteins better resists temperature extremes, whereas hydrated pollen does not (Franchi et al. 2011; Firon et al. 2012). Although the pollen water content of the study species is not known, its typical properties (Franchi et al. 2002) suggest that pollen of saxifrages and of $R$. glacialis is desiccation tolerant and that of $C$. uniflorum and $R$. ferrugineum is desiccation-susceptible.

Overall, it is to be expected that single reproductive structures of heat-susceptible species are already heat injured between 42 and $43{ }^{\circ} \mathrm{C}$ and that those of more heat-tolerant species become damaged at temperatures of $44-46{ }^{\circ} \mathrm{C}$ onwards. Depending on the structure concerned, even localized and slight heat damage can result in a total functional loss of a reproductive unit. Damage in the pedicel or peduncle automatically leads to the dieback of the whole flower or inflorescence (Neuner et al. 2013). Heat injury to the stigma and style leads to a complete loss of the progeny. Impairment of the corolla reduces the attractiveness for pollinators, which possibly leads to a reduced reproductive fitness of a flower, but not necessarily to a total reproductive loss. Damage to pollen affects the male fitness of the individuals concerned. Depending on the number of affected individuals within a population the genotypic variability of the progeny would become more or less reduced.

The expectation that reproductive structures in nival species are more susceptible to heat than those of species from lower elevations was only partly confirmed by our results. The nival species $R$. glacialis was clearly the most heat susceptible of the study plants, with little difference between 
reproductive and vegetative structures. This is consistent with earlier findings on leaf functions showing impairment from about $40{ }^{\circ} \mathrm{C}$ onward (Larcher et al. 1997). Reproductive structures of the nival species $S$. bryoides and C. uniflorum tolerated slightly more heat. The reproductive structures of the subalpine $R$. ferrugineum and alpine $S$. caesia had about the same low heat tolerance, which is in contrast to the relatively higher heat tolerance shown by their vegetative shoots. C. vulgaris (subalpine-alpine), L. procumbens (subalpine-alpine), S. oppositifolia and S. acaulis (both alpine-nival) tolerated the most heat. This ranking clearly shows that heat tolerance of reproductive structures, similar to that of vegetative organs, primarily depends on the species-specific heat load prevailing in the respective environment. Species clearly have a basic heat tolerance according to the heat load they usually experience. Starting from this basis, heat tolerance can, at least in leaves, increase in response to rising temperatures (Gauslaa 1984; Neuner et al. 2000; Buchner and Neuner 2003; reviewed in Neuner and Buchner 2012). We do not know whether reproductive structures are capable of heat hardening. It is however assumed that heat hardening is-similar to frost hardening (Neuner et al. 2013)—-limited in the permanently structurally and functionally changing reproductive tissues.

\section{Risk assessment for heat damage of reproductive shoots}

Daily air temperature maxima of $>14{ }^{\circ} \mathrm{C}$-temperatures at which prostrate plants can potentially heat above the temperature threshold causing heat damage-occurred on $60 \%$ of summer days at the treeline and on $30 \%$ of days in the alpine zone. However, as shown in Fig. 10a, measured plant temperatures in the risk range remained mostly below the damage threshold, indicating that high air temperatures alone do not necessarily cause lethal overheating in plants. As long as plants are sufficiently supplied with water and transpirational cooling is effective, the risk of lethal overheating may be low (Körner and De Moraes 1979; Neuner et al. 1999). However, the risk of overheating is high under conditions of high irradiation, calm air and dry soils, as shown by Neuner et al. (1999) and Buchner and Neuner (2003). Principally, the risk potential for individual plants differs according to the microsite conditions and the resulting small-scale temperature mosaic (Scherrer and Körner 2010). In cases of longer heat waves combined with drought, however, extensive heat damage at the community level is to be expected, as observed in the exceptionally warm summer 2003 (see following text).

Critical overwarming of plants can occur at any time during the summer months June-August and less often in May. Therefore, heat-endangered species are prone to suffer from heat damage during all reproductive stages. Daily temperature maxima are usually measured at midday and during the early afternoon. In our study, threshold values refer to 30-min short-term heating. As heat effects are dose-dependent (Kappen and Zeidler 1977), temperature thresholds for heat damage may become lower in cases of extended heating. In general, the dose effect is poorly investigated and should be considered in future studies on heat effects in plants.

We were able to show that acaulescent buds, flowers and fruits near the ground have the highest potential to suffer damage from heat. This is particularly true for the flat-growing dwarf shrub L. procumbens and the cushion plant $S$. oppositifolia, which at their respective growing sites reach maximum temperatures in the range of the heat damage threshold (30-min basis). When exposed to prolonged heating, the buds of the cushion plants $S$. caesia, S. moschata and S. bryoides (at lower sites) might be endangered. The remainder of the study species showed a sufficiently large safety margin between maximum plant temperature and heat damage threshold. Temperatures in reproductive structures situated $5-10 \mathrm{~cm}$ aboveground are usually far below the heat tolerance thresholds. Targeted in situ measurements in our study and in earlier studies (Larcher and Wagner 1983, 2010) demonstrated that caulescent flowers/inflorescences rarely warm up to $>35{ }^{\circ} \mathrm{C}$ because they are constantly moving due to air convection. Remarkably, in closed alpine grassland, caulescent flowers heat up more than the leaf canopy, as shown by Dietrich and Körner (2014) in a field survey on 43 species. In their study, at high solar radiation the difference reached up to $12 \mathrm{~K}$ in some species, with the highest measured absolute temperature being $39^{\circ} \mathrm{C}$ in compound flowers of Aster alpinus; in cushion plants, petals of sessile open flowers were found to be slightly cooler than the densely packed leaf canopy. These results are in accordance with our observations in Silene acaulis. Galen (2006) demonstrated that under warm conditions transpirational cooling by the perianth reduces the excess of heat, which might reduce the risk of thermal damage. However, this mechanism apparently does not hold for deep-seated floral structures, as ovaries experience the same overheating as the cushion foliage and thus are at risk of being heat damaged.

In summers characterized by regular precipitation and the absence of long periods of excessive heat, all of the plant species investigated here seem to be well adapted to the thermal situation in their environment. Generally, longer and warmer seasons are beneficial for reproductive output (e.g. Kudo 1991; Molau 1997, Wagner and Reichegger 1997; Arft et al. 1999; Ladinig and Wagner 2005; Klady et al. 2011; Ertl 2013). However, excessive heat, as occurred in 2003, can cause substantial reproductive losses, particularly in lower alpine belts and in plants on shallow soil (Jolly et al. 2005; Ladinig and Wagner 
2005, 2007; Abeli et al. 2012a; Wagner et al. 2012). Plants may recover when regular summers follow, and a reduced reproductive performance during heat waves may even be overcompensated for in the following year as resources are saved by non-flowering plants (Abeli et al. 2012b). The situation will be different when hot and dry summers become more frequent, which is expected as a consequence of rising global temperatures. The greatest temperature increase is anticipated in mountain systems and in the arctic/subarctic (Beniston et al.1997; Saetersdal and Birks 1997; Arft et al. 1999; Theurillat and Guisan 2001; Beniston 2003; Nogués-Bravo et al. 2007). The warming effect puts particular pressure on plant populations at the margins of their ecological ranges (Lesica and McCune 2004; Abeli et al. 2012b). Although elevated temperatures do not necessarily cause heat damage, excessive warmth can negatively affect physiological processes and, subsequently, productivity and reproductive performance in plants from cold ecosystems (Marchand et al. 2006; Orsenigo et al. 2014 for review). As a consequence, thermophilous species may replace the less competitive and slow-growing cryophilic species of open habitats, as already evidenced for several summit sites in European mountain systems (Gottfried et al. 2012; Dullinger et al. 2012). Similarly, simulation studies on climate warming in open-top chambers in mountain areas have shown that less competitive species will not benefit from an increase in temperatures (Stenström et al. 1997; Totland and Alatalo 2002; Kudo and Suzuki 2003; Liu et al. 2012). In addition to the competitive pressure caused by differences in growth strength and height, a heat-related decrease in reproductive output in heat-susceptible species could enhance the process of displacement.

Heat effects on the reproductive performance of alpine and arctic species are poorly investigated. Among the reproductive functions, floral induction is particularly susceptible to developmental disturbances. Higher temperatures are known to cause imbalances in signaling and the regulation of resource allocation, which may promote vegetative growth to the disadvantage of generative development (Ruan et al. 2010). In most alpine plants, floral initiation starts in the season before anthesis (Körner 2003; Wagner et al. 2012, and citations therein). Environmental conditions at that time have a significant influence on the number of shoots becoming floral and giving rise to inflorescences in the following year. Warm temperatures may remove the vernalization effect, as has been observed in several mountain species on the Tibetan Plateau (Liu et al. 2012) and for S. caesia (A. Seiwald and J. Wagner, unpublished results). Abeli et al. (2012b) conducted a long-term study on the inflorescence production of four alpine plant species and found an individualistic response to temperature. Depending on the species, more summer warmth either stimulated floral induction or led to a decline in inflorescence formation. Equally prone to malfunction are meiosis, pollen-tube growth and pistil functions, which are already disturbed by exposure to $30{ }^{\circ} \mathrm{C}$ for few hours (for mountain plants, see Steinacher and Wagner 2012). Generally, excessive heat waves negatively affect fruit set in alpine plants (Orsenigo et al. 2014), particularly in combination with drought (Giménez-Benavides et al. 2007). Reproduction in a broader sense also includes germination and seedling growth - two further developmental stages which are most vulnerable to climatic extremes. On average, seedling mortality rates of alpine plant species are within the rates for a wide range of perennial species (Forbis 2003; Forbis and Doak 2004); however, they drastically increase at stress-dominated bare ground sites (Niederfriniger and Erschbamer 2000). There, in addition to frost (Marcante et al. 2012), heat and drought are major threats to seedling growth (Marcante et al. 2014).

It can be assumed that the individualistic response of species to heat will alter the population dynamics and thereby the composition of plant communities. Species with low rates of recruitment, due to an increased frequency of extreme weather events, will be disadvantaged compared to more heat-tolerant species with a higher reproductive capacity (Abeli et al. 2014). To better understand the impact of rising temperatures on the reproduction of different high-mountain species, it is not only important to know the temperatures at which reproductive tissues are killed, but also the high temperature thresholds for successful reproductive functioning.

Author contribution statement UL planned, conceived and performed most of the experiments, analysed the data and wrote parts of the manuscript; MP performed infrared video thermography, IB carried out pollen germination tests, SZ contributed substantially to the assessment of heat tolerance, GN contributed to the concept and provided editorial advice, JW contributed to the concept and wrote the final version of the manuscript.

Acknowledgments This research was funded by the Austrian Science Fund (FWF): P20010-B16. We thank O. Buchner and G. Wieser for the temperature data. We also thank the Central Institute for Meteorology and Geodynamics (Regional Center for Tirol and Vorarlberg) for providing meteorological data, and the Stubaier Gletscherbahn and the Patscherkofelbahn for free transportation by cable-car. We also thank two anonymous reviewers for their valuable comments on an earlier version of the manuscript.

\section{Conflict of interest None}

Open Access This article is distributed under the terms of the Creative Commons Attribution License which permits any use, distribution, and reproduction in any medium, provided the original author(s) and the source are credited. 


\section{References}

Abeli T, Rossi G, Gentili R, Gandini M, Mondoni A, Cristofanelli P (2012a) Effect of the extreme summer heat waves on isolated populations of two orophitic plants in the north Apennines (Italy). Nord J Bot 30:109-115. doi:10.1111/j.1756-1051.2011.01303.x

Abeli T, Rossi G, Gentili R, Mondoni A, Cristofanelli P (2012b) Response of alpine plant flower production to temperature and snow cover fluctuation at the species range boundary. Plant Ecol 213:1-13. doi:10.1007/s11258-011-0001-5

Abeli T, Jäkäläniemi A, Gentili R (2014) Living with extremes: the dark side of global change. Plant Ecol 215:673-675. doi:10.1007/ s11258-014-0373-675

Arft AM, Walker MD, Gurevitch J et al (1999) Responses of tundra plants to experimental warming: meta-analysis of the international tundra experiment. Ecol Monogr 69:491-511. doi:10.2307/2657227

Barnabás B, Jäger K, Fehér A (2008) The effect of drought and heat stress on reproductive processes in cereals. Plant Cell Environ 31:11-38. doi:10.1111/j.1365-3040.2007.01727.x

Beniston M (2003) Climatic change in mountain regions: a review of possible impacts. Clim Change 59:5-31. doi:10.102 3/A:1024458411589

Beniston M, Diaz HF, Bradley RS (1997) Climatic change at high elevation sites: an overview. Clim Change 36:233-251

Boavida LC, Mc Cormick S (2007) Temperature as a determinant factor for increased and reproducible in vitro pollen germination in Arabidopsis thaliana. Plant J 52:570-582. doi:10.1111/j.1365-313X.2007.03248.x

Buchner O, Neuner G (2001) Determination of heat tolerance: a new equipment for field measurements. J Appl Bot 75:130-137. doi:10.1186/1746-4811-9-7

Buchner O, Neuner G (2003) Variability of heat tolerance in alpine plant species measured at different altitudes. Arct Antarct Alp Res 35:411-420

Buchner O, Karadar M, Bauer I, Neuner G (2013) A novel system for in situ determination of heat tolerance of plants: first results on alpine dwarf shrubs. Plant Methods 9:7. doi:10.1186/1746-4811-9-7

Cernusca A (1976) Bestandesstruktur, Bioklima und Energiehaushalt von alpinen Zwergstrauchbeständen. Oecol Plant 11:71-102

Davis MB, Shaw RG (2001) Range shifts and adaptive responses to quaternary climate change. Science 292:673-679

Dietrich L, Körner C (2014) Thermal imaging reveals massive heat accumulation in flowers across a broad spectrum of alpine taxa. Alp Bot. 124:27-35. doi:10.1007/s00035-014-0123-1

Dullinger S, Gattringer A, Thuiller W et al (2012) Extinction dept of high-mountain plants under twenty-first-century climate change. Nat Clim Chang 2:619-622

Ellenberg H, Leuschner C (2010) Vegetation Mitteleuropas mit den Alpen, 6th edn. Ulmer, Stuttgart

Ertl S (2013) Positive effects of an extremely hot summer on propagule rain in upper alpine to subnival habitats of the Central Eastern Alps. Plant Ecol Div 6:467-474. doi:10.1080/17550874.201 3.807885

Firon N, Nepi M, Pacini E (2012) Water status and associated processes mark critical stages in pollen development and functioning. Ann Bot 109:1201-1213. doi:10.1093/aob/mcs070

Forbis TA (2003) Seedling demography in an alpine ecosystem. Am J Bot 90:1197-1206

Forbis TA, Doak DF (2004) Seedling establishment and life history trade-offs in alpine plants. Am J Bot 91:1147-1153

Franchi GG, Nepi M, Dafni A, Pacini E (2002) Partially hydrated pollen: taxonomic distribution, ecological and evolutionary significance. Plant Syst Evol 234:211-227. doi:10.1007/ s00606-002-0221-1
Franchi GG, Piotto B, Nepi M, Baskin CC, Baskin JM, Pacini E (2011) Pollen and seed desiccation tolerance in relation to degree of developmental arrest, dispersal, and survival. J Exp Bot 62:5267-5281. doi:10.1093/jxb/err154

Galen C (2006) Solar furnaces or swamp coolers: costs and benefits of water use by solar-tracking flowers of the alpine snow buttercup, Ranunculus adoneus. Oecologia 148:195-201

Galen C, Stanton ML (2003) Sunny-side up: flower heliotropism as a source of parental environmental effects on pollen quality and performance in the snow buttercup, Ranunculus adoneus (Ranunculaceae). Am J Bot 90:724-729. doi:10.3732/ajb.90.5.724

Gauslaa Y (1984) Heat resistance and energy budget in different Scandinavian plants item citation. Holarctic Ecol 7:5-78

Giménez-Benavides L, Escudero A, Iriondo JM (2007) Reproductive limits of a late-flowering high-mountain Mediterranean plant along an elevational climate gradient. New Phytol 173:367-382. doi:10.1111/j.1469-8137.2006.01932.x

Gottfried M, Pauli H, Futschik A et al (2012) Continent-wide response of mountain vegetation to climate change. Nat Clim Chang 2:111-115. doi:10.1038/nclimate1329

Hedhly A (2011) Sensitivity of flowering plant gametophytes to temperature fluctuations. Environ Exp Bot 74:9-16. doi:10.1016/j. envexpbot.2011.03.016

Hedhly A, Hormaza JI, Herrero M (2003) The effect of temperature on stigmatic receptivity in sweet cherry (Prunus avium L.). Plant Cell Environ 26:1673-1680. doi:10.1046/j.1365-3040.2003.01085.x

Hedhly A, Hormaza JI, Herrero M (2008) Global warming and sexual plant reproduction. Trends Plant Sci 14:30-36. doi:10.1046/j.1365-3040.2003.01085.x

Hegi G (1975) Illustrierte Flora von Mitteleuropa, vol. 3. Paul Parey, Berlin

Jolly WM, Dobbertin M, Zimmermann NE, Reichstein M (2005) Divergent vegetation growth responses to the 2003 heat wave in the Swiss Alps. Geophys Res Lett 32:1-4. doi:10.1029/200 5GL023252

Kaplan K (1995) Saxifragaceae. In: Weber HE (ed) Gustav HegiIllustrierte Flora von Mitteleuropa,, vol. 4/2A. Blackwell, Berlin, pp 130-229

Kappen L, Zeidler A (1977) Seasonal changes between one- and twophasic response of plant leaves to heat stress. Oecologia 31:4553. doi:10.1007/BF00348707

Kevan PG (1975) Sun-tracking solar furnaces in high Arctic flowers: significance for pollination and insects. Science 189:723-726. doi:10.1126/science.189.4204.723

Klady R, Henry GHR, Lemay V (2011) Changes in high arctic tundra plant reproduction in response to long-term experimental warming. Glob Chang Biol 17:1611-1624. doi:10.1111/j.1365-2486.2010.02319.x

Körner C (2003) Alpine plant life, 2nd edn. Springer, Berlin

Körner C (2011) Coldest place on earth with angiosperm plant life. Alp Bot 121:11-22. doi:10.1007/s00035-011-0089-1

Körner C, Cochrane P (1983) Influence of plant physiognomy on leaf temperature on clear midsummer days in the snowy mountains, south-eastern Australia. Acta Oecol 4:17-124

Körner C, De Moraes JAPV (1979) Water potential and diffusion resistance in alpine cushion plants on clear summer days. Oecol Plant 14:109-120

Körner C, Larcher W (1988) Plant life in cold climates. Plants and temperature. In: Long SF, Woodward FI (eds) Symposia of the Society for Experimental Biology, vol 42. The Company of Biologists Ltd, Cambridge, pp 25-57

Kreeb K (1990) Methoden zur Pflanzenökologie und Bioindikation. Gustav Fischer, Stuttgart

Kudo G (1991) Effects of snow-free period on the phenology of alpine plants inhabiting snow patches. Arct Alp Res 23:436-443 
Kudo G, Suzuki S (2003) Warming effects on growth, production, and vegetation structure of alpine shrubs: a five-year experiment in northern Japan. Oecologia 135:280-287. doi:10.1007/ s00442-003-1179-6

Ladinig U, Wagner J (2005) Sexual reproduction of the high mountain plant Saxifraga moschata Wulfen at varying lengths of the growing season. Flora 200:502-515. doi:10.1016/j.flora.2005.06.002

Ladinig U, Wagner J (2007) Timing of sexual reproduction and reproductive success in the high mountain plant Saxifraga bryoides L. Plant Biol 9:683-693. doi:10.1055/s-2007-965081

Ladinig U, Hacker J, Neuner G, Wagner J (2013) How endangered is sexual reproduction of high-mountain plants by summer frosts? Frost resistance, frequency of frost events and risk assessment. Oecologia 171:743-760. doi:10.1007/s00442-012-2581-8

Landolt E (1992) Unsere alpenflora. Fischer, Stuttgart

Larcher W, Wagner J (1976) Temperaturgrenzen der CO2-Aufnahme und Temperaturresistenz der Blätter von Gebirgspflanzen im vegetationsaktiven Zustand. Oecol Plant 11:361-374

Larcher W, Wagner J (1983) Ökologischer Zeigerwert und physiologische Konstitution von Sempervivum montanum. Verh Ges Ökologie 11:245-264

Larcher W, Wagner J (2009) High mountain bioclimate: temperatures near the ground recorded from the timberline to the nival zone in the Central Alps. Contrib Nat Hist Berne 12:857-874

Larcher W, Wagner J (2010) Temperatures in the life zones of the Tyrolean Alps. Österreichische Akademie der Wissenschaften, Mathematisch-Naturwissenschaftliche Klasse Abteilung I. Biol Wissensch Erdwissensch 213:31-51

Larcher W, Wagner J, Lütz C (1997) The effect of heat on photosynthesis, dark respiration and cellular ultrastructure of the arctic-alpine psychrophyte Ranunculus glacialis. Photosynthetica 34:219-232. doi:10.1023/A:1006840623763

Larcher W, Kainmüller C, Wagner J (2010) Survival types of high mountain plants under extreme temperatures. Flora 205:3-18. doi:10.1016/j.flora.2008.12.005

Lesica PB, McCune B (2004) Decline of arctic-alpine plants at the southern margin of their range following a decade of climatic warming. J Veg Sci 15:679-690

Liu Y, Mu J, Niklas KJ, Li G, Sun S (2012) Global warming reduces plant reproductive output for temperate multi-inflorescence species on the Tibetan plateau. New Phytol 195:427-436. doi:10.1111/j.1469-8137.2012.04178.x

Luzar N, Gottsberger G (2001) Flower heliotropism and floral heating of five alpine plant species and the effect on flower visiting in Ranunculus montanus in the Austrian Alps. Arct Antarct Alp Res 33:93-99

Marcante S, Sierra-Almeida A, Spindelböck J, Erschbamer B, Neuner G (2012) Frost as a limiting factor for recruitment and establishment of early developmental stages in an alpine glacier foreland? J Veg Sci 23:858-868. doi:10.1111/j.1654-1103.2012.01411.x

Marcante S, Erschbamer B, Buchner O, Neuner G (2014) Heat tolerance of early developmental stages of glacier foreland species in the growth chamber and in the field. Plant Ecol 215:747-758. doi:10.1007/s11258-014-0361-8

Marchand FL, Kockelbergh F, van de Vijver B, Beyens L, Nijs I (2006) Are heat and cold resistance of arctic species affected by successive extreme temperature events? New Phytol 170:291-300

Molau U (1997) Phenology and reproductive success in arctic plants: susceptibility to climate change. In: Oechel WC, Callaghan T, Gilmanov T, Holten JI, Maxwell B, Molau U, Sveinbjörnsson B (eds) Global change and arctic terrestrial ecosystems. Ecological studies, vol 124. Springer, Berlin Heidelberg, pp 153-170

Nepi M, Franchi GG, Pacini E (2001) Pollen hydration status at dispersal: cytophysiological features and strategies. Protoplasma 216:171-180. doi:10.1007/BF02673869
Neuner G, Beikircher B (2010) Critically reduced frost resistance of Picea abies during sprouting in relation to cytological changes. Protoplasma 243:145-152. doi:10.1007/s00709-009-0052-9

Neuner G, Buchner O (2012) Dynamic of tissue heat tolerance and thermotolerance of PS II in alpine plants. In: Lütz C (ed) Plants in alpine regions: cell physiology of adaptation and survival strategies. Springer, Vienna, pp 61-74. doi:10.1007/978-3-7091-0136-0_6

Neuner G, Braun V, Buchner O, Taschler D (1999) Leaf rosette closure in the alpine rock species Saxifraga paniculata Mill.: significance for survival of drought and heat under high irradiation. Plant Cell Environ 22:1539-1548. doi:10.1046/j.1365-3040.1999.00508.x

Neuner G, Buchner O, Braun V (2000) Short-term changes in heat tolerance in the alpine cushion plant Silene acaulis ssp. excapa [All.] J. Braun at different altitudes. Plant Biol 2:677-683. doi:10 $.1055 / \mathrm{s}-2000-16635$

Neuner G, Erler A, Ladinig U, Hacker J, Wagner J (2013) Frost resistance of reproductive tissues during various stages of development high-mountain plants. Physiol Plant 147:88-100. doi:10.1111/j.1399-3054.2012.01616.x

Niederfriniger-Schlag R, Erschbamer B (2000) Germination and establishment of seedlings on a glacier foreland in the Central Alps, Austria. Arct Antarct Alp Res 32:270-277

Nogués-Bravo D, Araujo MB, Errea MP, Martínez-Rica JP (2007) Exposure of global mountain systems to climate warming during the 21st Century. Global Environ Chang 17:420-428

Orsenigo S, Mondoni A, Rossi G, Abeli T (2014) Some like it hot and some like it cold, but not too much: plant responses to climate extremes. Plant Ecol 215:677-688. doi:10.1007/ s11258-014-0363-6

Raunkiaer C (1934) The life forms of plants and statistical plant geography. Clarendon Press, Oxford

Rejšková A, Pokorny Brom J, Korečko J (2010) Temperature distribution in light-coloured flowers and inflorescences of early spring temperate species measured by infrared camera. Flora 205:282289. doi:10.1016/j.flora.2009.05.001

Ruan Y-L, Jin Y, Yang Y-J, Li G-J, Boyer JS (2010) Sugar input, metabolism, and signalling mediated by invertase: roles in development, yield potential, and response to drought and heat. Mol Plant 3:942-955

Saetersdal M, Birks HJB (1997) A comparative ecological study of Norwegian mountain plants in relation to possible future climatic change. J Biogeogr 24:127-152. doi:10.104 6/j.1365-2699.1997.00096

Salisbury FB, Spomer GG (1964) Leaf temperatures of alpine plants in the field. Planta 60:497-505

Scherrer D, Körner C (2010) Infra-red thermometry of alpine landscapes challenges climatic warming projections. Glob Chang Biol 16:2602-2613. doi:10.1111/j.1365-2486.2009.02122.x

Stanton ML, Galen C (1989) Consequences of flower heliotropism for reproduction in an alpine buttercup (Ranunculus adoneus). Oecologia 78:477-485. doi:10.1007/BF00378737

Steinacher G, Wagner J (2012) Effect of temperature on the progamic phase in high-mountain plants. Plant Biol. 14:295-305. doi:10.1111/j.1438-8677.2011.00498.x

Stenström M, Gugerli F, Henry GHR (1997) Response of Saxifraga oppositifolia $\mathrm{L}$. to simulated climate change at three contrasting latitudes. Glob Chang Biol 3:44-54. doi:10.1111/j.1365-2486.1997.gcb144.x

Taschler D, Beikircher B, Neuner G (2004) Frost resistance and ice nucleation in leaves of five woody timberline species measured in situ during shoot expansion. Tree Physiol 24:331-337. doi:10.1093/treephys/24.3.331

Theurillat JP, Guisan A (2001) Potential impact of climate change on vegetation in the European Alps: a review. Clim Chang 50:77109. doi:10.1023/A:1010632015572 
Totland O, Alatalo JM (2002) Effects of temperature and date of snowmelt on growth, reproduction and flowering phenology in the arctic/alpine herb, Ranunculus glacialis. Oecologia 133:168 175. doi:10.1007/s00442-002-1028-z

Tripathi SK, Tuteja N (2007) Integrated signaling in flower senescence: an overview. Plant Signal Behav 2:437-445

van Doorn WG, Woltering EJ (2008) Physiology and molecular biology of petal senescence. J Exp Bot 59:453-480. doi:10.1093/jxb/ erm 356

Wagner J, Reichegger B (1997) Phenology and seed development of the alpine sedges Carex curvula and Carex firma in response to contrasting topoclimates. Arct Alp Res 29:291-299
Wagner J, Ladinig U, Steinacher G, Larl I (2012) From the flower bud to the mature seed: timing and dynamics of flower and seed development in high-mountain plants. In: Lütz C (ed) Plants in alpine regions. Springer, Vienna. doi:10.1007/978-3-7091-0136-0_10

Wilson C, Grace J, Allen S, Slack F (1987) Temperature and stature: a study of temperatures in montane vegetation. Funct Ecol 1:405-413

Zimmermann W (1975) Ranunculaceae. In: Rechinger KH, Damboldt J (eds)Gustav Hegi-Illustrierte Flora von Mitteleuropa, vol. 3/3. Paul Parey, Berlin

Zinn KE, Tunc-Ozdemir M, Harper JF (2010) Temperature stress and plant sexual reproduction: uncovering the weakest links. J Exp Bot 61:1959-1968. doi:10.1093/jxb/erq053 